\title{
Cardiac magnetic resonance imaging; gatekeeper in suspected CAD?
}

\author{
E. E. van der Wall $\cdot$ H. M. Siebelink • \\ J. J. Bax • M. J. Schalij
}

Received: 10 June 2010/Accepted: 14 June 2010/Published online: 23 June 2010

(C) The Author(s) 2010. This article is published with open access at Springerlink.com

Nowadays, the impact of cardiovascular imaging on the overall healthcare system is substantial. Every year five billion imaging tests are performed worldwide, and about half of these are cardiovascular examinations [1-3]. It is estimated that nearly 8 million SPECT studies are now performed annually in the US compared to 4 million studies in 1998. Considering the additional 2.8 million stress echocardiograms, the total number of stress imaging studies in the US was nearly 11 million in 2006. More importantly, one might measure patient selection, which is a key variable impacting directly on clinical management, downstream testing procedures, and -in particular- costs. Otero et al. [1] have shown that each test represents a cost and a risk, and that very small individual costs and risks become significant when multiplied by the large number of tests performed worldwide annually. This important concept has far-reaching implications. The cost of a medical imaging test has three different components: immediate cost; long-term cost (for instance, due to a new cancer developing decades after testing, as a

Editorial comment to the article of Pilz et al. (doi: 10.1007/s10554-010-9645-9)

E. E. van der Wall $(\bowtie) \cdot$ H. M. Siebelink ·

J. J. Bax · M. J. Schalij

Department of Cardiology, Leiden University Medical

Center, P.O. Box 9600, Leiden, The Netherlands

e-mail: e.e.van_der_wall@lumc.nl consequence of the imaging test); and a societal cost due to the possible environmental impact of the imaging procedure. The American College of Cardiology (ACC) and the subspecialty imaging societies have provided this quality issue by focusing on the development of appropriateness criteria for cardiovascular imaging which are designed to define the appropriate test for the appropriate indication in the appropriate patient [4]. According to recent estimates, at least one-third of all examinations are partially or totally inappropriate, i.e. risks and costs outweigh benefits. In a context of scarce resources, and consequently the need to optimize their allocation, economic evaluation could play an important role in establishing a cost-effective health care program and supporting the decisions of policymakers? The first appropriateness criteria were developed for SPECT myocardial perfusion imaging followed shortly thereafter with appropriateness criteria for echocardiography, cardiac computed tomography (CT), and cardiac magnetic resonance imaging (CMR) [5-16]. Both CMR and CT still have a lower profile in the economic market, but they are growing steadily [17-41]. CMR is currently not or not sufficiently reimbursed presumably because of limited evidence-based studies. It is not fully known whether CMR can be effectively used to facilitate medical decision-making and reduce costs by serving as a gatekeeper to invasive coronary angiography.

In the current issue of the International Journal of Cardiovascular Imaging, Pilz et al. [42] investigated 
whether the use of CMR in patients suspected for coronary artery disease (CAD) reduced costs by avoiding referrals to invasive procedures. Propensity score methods were used to match 218 patients from a CMR registry to a previously studied cohort in whom CMR was demonstrated to reliably identify patients who were at low-risk for major cardiac events. The proportion of patients was assessed for whom cardiac catheterization was deferred based on CMR findings. CMR reduced the utilization of cardiac catheterization by $62.4 \%$. Based on estimated catheterization costs of $€ 619$, the utilization of CMR as a gatekeeper reduced per-patient costs by a mean of $€ 90$. CMR significantly reduced the utilization of cardiac catheterization in patients suspected of having CAD. Per-patient savings ranged from $€ 323$ in patients at lowest risk of CAD to $€ 58$ in patients at high-risk. Because a negative CMR study has a high negative predictive value, its use as a gatekeeper to cardiac catheterization is a worthwhile option in patients with suspected CAD who are considered for cardiac catheterization.

These findings are in line with previous noninvasive imaging studies which clearly showed a gatekeeper role for SPECT imaging in referral to invasive coronary arteriography $[43,44]$. In the Economics of Noninvasive Diagnosis (END) study, Shaw et al. [43] compared two patient management strategies consisting of (1) direct cardiac catheterization (aggressive strategy), or (2) initial SPECT followed by selective catheterization of high risk patients (conservative strategy). The authors prospectively enrolled 11,372 consecutive stable angina patients who were referred for SPECT or cardiac catheterization. It was shown that stable chest pain patients who underwent a more aggressive diagnostic strategy had higher diagnostic costs and greater rates of intervention and follow-up costs. In the EMPIRE study, Underwood et al. [44] showed that investigative strategies using myocardial perfusion imaging were cheaper and equally effective when compared with strategies that did not use myocardial perfusion imaging, both for cost of diagnosis and for overall 2 year management costs. In an ongoing study, Groothuis et al. [45] combines multi-detector CT and CMR to provide the clinician a strategy with the aim to comprehensively evaluate coronary morphology and function noninvasively. In the MARCC trial (Magnetic Resonance and CT in suspected CAD) a new noninvasive diagnostic work-up for patients with suspected CAD will be developed, involving the sequential use of both imaging techniques.

Although the results of the current study are still preliminary, Pilz et al. [42] have clearly shown that procedural costs in patients suspected for CAD would substantially decrease when CMR is routinely applied as a gatekeeper to cardiac catheterization.

Open Access This article is distributed under the terms of the Creative Commons Attribution Noncommercial License which permits any noncommercial use, distribution, and reproduction in any medium, provided the original author(s) and source are credited.

\section{References}

1. Otero JH, Rybicki FJ, Greenberg D, Mitsouras D, Mendoza J, Neumann PJ (2010 ) Cost-effective diagnostic cardiovascular imaging: when does it provide good value for money? Int J Cardiovasc Imaging. 2010 May 6. [Epub ahead of print]

2. Leo CG, Carpeggiani C, Picano E (2010) Cost and benefit in cardiovascular imaging: the quest for economic sustainability. Int J Cardiovasc Imaging. 2010 May 1. [Epub ahead of print]

3. van der Wall EE, Vliegen HW, de Roos A, Bruschke AV (1995) Magnetic resonance imaging in coronary artery disease. Circulation 92:2723-2739

4. Hendel RC (2008) The revolution and evolution of appropriateness in cardiac imaging. J Nucl Cardiol 15: 494-496

5. Picano E, Pasanisi E, Brown J, Marwick TH (2007) A gatekeeper for the gatekeeper: inappropriate referrals to stress echocardiography. Am Heart J 154:285-290

6. Bavelaar-Croon CD, Kayser HW, van der Wall EE et al (2000) Left ventricular function: correlation of quantitative gated SPECT and MR imaging over a wide range of values. Radiology 217:572-575

7. van Lennep JE, Westerveld HT, van Lennep HW, Zwinderman AH, Erkelens DW, van der Wall EE (2000) Apolipoprotein concentrations during treatment and recurrent coronary artery disease events. Arterioscler Thromb Vasc Biol 20:2408-2413

8. van der Wall EE, den Hollander W, Heidendal GA, Westera G, Majid PA, Roos JP (1981) Dynamic myocardial scintigraphy with $123 \mathrm{I}$-labeled free fatty acids in patients with myocardial infarction. Eur J Nucl Med 6:383-389

9. Braun S, van der Wall EE, Emanuelsson S, Kobrin I (1996) Effects of a new calcium antagonist, mibefradil (Ro 405967), on silent ischemia in patients with stable chronic angina pectoris: a multicenter placebo-controlled study. The mibefradil international study group. J Am Coll Cardiol 27:317-322

10. Ypenburg C, Roes SD, Bleeker GB et al (2007) Effect of total scar burden on contrast-enhanced magnetic resonance imaging on response to cardiac resynchronization therapy. Am J Cardiol 99:657-660 
11. Ypenburg C, van der Wall EE, Schalij MJ, Bax JJ (2008) Imaging in cardiac resynchronisation therapy. Neth Heart $\mathrm{J}$ 16:S36-S40

12. Oemrawsingh PV, Mintz GS, Schalij MJ, Zwinderman AH, Jukema JW, van der Wall EE (2003) Intravascular ultrasound guidance improves angiographic and clinical outcome of stent implantation for long coronary artery stenoses: final results of a randomized comparison with angiographic guidance (TULIP study). Circulation 107:62-67

13. van Rugge FP, Holman ER, van der Wall EE et al (1993) Quantitation of global and regional left ventricular function by cine magnetic resonance imaging during dobutamine stress in normal human subjects. Eur Heart J 14:456-463

14. Tops LF, Schalij MJ, Holman ER, van Erven L, van der Wall EE, Bax JJ (2006) Right ventricular pacing can induce ventricular dyssynchrony in patients with atrial fibrillation after atrioventricular node ablation. J Am Coll Cardiol 48:1642-1648

15. Schuijf JD, Bax JJ, van der Wall EE (2007) Anatomical and functional imaging techniques: basically similar or fundamentally different? Neth Heart J 15:43-44

16. Nemes A, Geleijnse ML, van Geuns RJ et al (2008) Dobutamine stress MRI versus threedimensional contrast echocardiography: it's all black and white. Neth Heart J $16: 217-218$

17. Vliegen HW, Doornbos J, de Roos A, Jukema JW, Bekedam MA, van der Wall EE (1997) Value of fast gradient echo magnetic resonance angiography as an adjunct to coronary arteriography in detecting and confirming the course of clinically significant coronary artery anomalies. Am J Cardiol 79:773-776

18. Hoogendoorn LI, Pattynama PM, Buis B, van der Geest RJ, van der Wall EE, de Roos A (1995) Noninvasive evaluation of aortocoronary bypass grafts with magnetic resonance flow mapping. Am J Cardiol 75:845-848

19. Portegies MC, Schmitt R, Kraaij CJ et al (1991) Lack of negative inotropic effects of the new calcium antagonist Ro 40-5967 in patients with stable angina pectoris. J Cardiovasc Pharmacol 18:746-751

20. Groenink M, Lohuis TA, Tijssen JG et al (1999) Survival and complication free survival in Marfan's syndrome: implications of current guidelines. Heart 82:499-504

21. Oosterhof T, van Straten A, Vliegen HW et al (2007) Preoperative thresholds for pulmonary valve replacement in patients with corrected tetralogy of Fallot using cardiovascular magnetic resonance. Circulation 116:545-551

22. Bleeker GB, Bax JJ, Fung JW et al (2006) Clinical versus echocardiographic parameters to assess response to cardiac resynchronization therapy. Am J Cardiol 97:260-263

23. Bleeker GB, Holman ER, Steendijk P et al (2006) Cardiac resynchronization therapy in patients with a narrow QRS complex. J Am Coll Cardiol 48:2243-2250

24. van der Laarse A, Kerkhof PL, Vermeer F et al (1988) Relation between infarct size and left ventricular performance assessed in patients with first acute myocardial infarction randomized to intracoronary thrombolytic therapy or to conventional treatment. Am J Cardiol 61:1-7

25. van der Laan A, Hirsch A, Nijveldt R et al (2008) Bone marrow cell therapy after acute myocardial infarction: the HEBE trial in perspective, first results. Neth Heart J 16: 436-439
26. Bakx AL, van der Wall EE, Braun S, Emanuelsson H, Bruschke AV, Kobrin I (1995) Effects of the new calcium antagonist mibefradil (Ro 40-5967) on exercise duration in patients with chronic stable angina pectoris: a multicenter, placebo-controlled study. Ro 40-5967 international study group. Am Heart J 130:748-757

27. Bleeker GB, Schalij MJ, Boersma E et al (2007) Relative merits of M-mode echocardiography and tissue Doppler imaging for prediction of response to cardiac resynchronization therapy in patients with heart failure secondary to ischemic or idiopathic dilated cardiomyopathy. Am J Cardiol 99:68-74

28. Ypenburg C, Sieders A, Bleeker GB et al (2007) Myocardial contractile reserve predicts improvement in left ventricular function after cardiac resynchronization therapy. Am Heart J 154:1160-1165

29. Torn M, Bollen WL, van der Meer FJ, van der Wall EE, Rosendaal FR (2005) Risks of oral anticoagulant therapy with increasing age. Arch Intern Med 165:1527-1532

30. Ypenburg C, Schalij MJ, Bleeker GB et al (2007) Impact of viability and scar tissue on response to cardiac resynchronization therapy in ischaemic heart failure patients. Eur Heart J 28:33-41

31. de Nooijer R, Verkleij CJ, von der Thüsen JH et al (2006) Lesional overexpression of matrix metalloproteinase-9 promotes intraplaque hemorrhage in advanced lesions but not at earlier stages of atherogenesis. Arterioscler Thromb Vasc Biol 26:340-346

32. de Roos A, Matheijssen NA, Doornbos J, van Dijkman PR, van Rugge PR, van der Wall EE (1991) Myocardial infarct sizing and assessment of reperfusion by magnetic resonance imaging: a review. Int J Card Imaging 7:133-138

33. van Rugge FP, van der Wall EE, van Dijkman PR, Louwerenburg HW, de Roos A, Bruschke AV (1992) Usefulness of ultrafast magnetic resonance imaging in healed myocardial infarction. Am J Cardiol 70:1233-1237

34. van der Wall EE, Bax JJ (2008) Late contrast enhancement by CMR: more than scar? Int J Cardiovasc Imaging 24:609-611

35. van der Wall EE, van Dijkman PR, de Roos A et al (1990) Diagnostic significance of gadolinium-DTPA (diethylenetriamine penta-acetic acid) enhanced magnetic resonance imaging in thrombolytic treatment for acute myocardial infarction: its potential in assessing reperfusion. Br Heart $\mathbf{J}$ 63:12-17

36. van der Wall EE, Heidendal GA, den Hollander W, Westera G, Roos JP (1980) I-123 labeled hexadecenoic acid in comparison with thallium-201 for myocardial imaging in coronary heart disease. A preliminary study. Eur J Nucl Med 5:401-405

37. van Rugge FP, Boreel JJ, van der Wall EE et al (1991) Cardiac first-pass and myocardial perfusion in normal subjects assessed by sub-second Gd-DTPA enhanced MR imaging. J Comput Assist Tomogr 15:959-965

38. Nijveldt R, Beek AM, Hirsch A et al (2008) 'No-reflow' after acute myocardial infarction: direct visualisation of microvascular obstruction by gadolinium-enhanced CMR. Neth Heart J 16:179-181

39. van der Geest RJ, de Roos A, van der Wall EE, Reiber JH (1997) Quantitative analysis of cardiovascular MR images. Int J Card Imaging 13:247-258 
40. van der Geest RJ, Niezen RA, van der Wall EE, de Roos A, Reiber JH (1998) Automated measurement of volume flow in the ascending aorta using MR velocity maps: evaluation of inter- and intraobserver variability in healthy volunteers. J Comput Assist Tomogr 22:904-911

41. Pilz G, Jeske A, Klos M et al (2008) Prognostic value of normal adenosine-stress cardiac magnetic resonance imaging. Am J Cardiol 101:1408-1412

42. Pilz G, Patel PA, Fell U et al (2010) Adenosine-stress cardiac magnetic resonance imaging in suspected coronary artery disease: a net cost analysis and reimbursement implications. Int J Cardiovasc Imaging. 2010 Jun 4. [Epub ahead of print]

43. Shaw LJ, Hachamovitch R, Berman DS et al (1999) The economic consequences of available diagnostic and prognostic strategies for the evaluation of stable angina patients: an observational assessment of the value of precatheterization ischemia. Economics of noninvasive diagnosis (END) multicenter study group. J Am Coll Cardiol 33:661-669

44. Underwood SR, Godman B, Salyani S, Ogle JR, Ell PJ (1999) Economics of myocardial perfusion imaging in Europe-the EMPIRE study. Eur Heart J 20:157-166

45. Groothuis JG, Beek AM, Meijerink MR, Brinckman SL, Hofman MB, van Rossum AC (2010) Towards a noninvasive anatomical and functional diagnostic work-up of patients with suspected coronary artery disease. Neth Heart J 18:270-273 